\title{
Acute Phase Proteins as Cancer Biomarkers
}

\author{
W. Shannon Orr¹, Linda H. Malkas², \\ Robert J. Hickey ${ }^{2}$ and John A. Sandoval ${ }^{1}$ \\ 1St. Jude Children's Research Hospital, Memphis TN \\ ${ }^{2}$ City of Hope Cancer Center, Duarte, CA \\ United States of America
}

\section{Introduction}

Interactions between tumor cells and the host microenvironment have been shown to play a significant role in the initiation, progression, and invasiveness of human cancer. The complex changes in the tumor microenvironment have been shown to modulate the activation of the different arms of the host immune system including the acute phase response. Acute phase changes are mediated by several serum proteins [acute phase proteins (APP)] whose concentrations may increase (positive APP) or decrease (negative APP) as a result of varied clinical conditions, including cancer. To date, a body of evidence suggests APP may have a profound impact on cancer growth and appear to court a protective immune response by co-opting the body's innate immune system. In this review, we discuss the impact of the host tumor response in relation to acute phase proteins and examine literature characterizing APP as helpful cancer biomarkers. Insights gained into the mechanism of action of acute-phase reactants towards malignancy and how they are induced could be exploited for the future development of more specific and targeted cancer biomarker strategies.

\section{Microenvironment and cancer}

In recent decades, the tumor microenvironment has received much attention as compelling evidence has demonstrated that a battery of various components interact to play a critical role in establishing fertile ground for tumor growth and progression. The neoplastic microenvironment roughly includes immune cells (lymphocytes, natural killer cells, and antigen presenting cells), stromal cells (including myofibroblasts), and vasculature (see Fig.1). Tumor microenvironment has been shown to contribute to tumor growth. Stromal cells stimulate cancer cell growth and invasion through the chemokine-chemokine receptor axis.(Orimo et al 2005;Polyak \& Hahn 2006) Tumor vasculature allows nutrients and oxygen uptake by tumors and tumor-infiltrating immune cells anergize the immune effectors. In the present work, we will review the relevant interactions between tumor microenvironment and solid tumors that aid in creating the conditions for supporting tumor cell survival and metastasis. In particular, one important response is the host reaction to a cancer that promotes an inflammatory microenvironment. It is clear that this inflammatory environment associated with solid tumors can exert pro-and and anti-tumor functions and this response can play a central role in modulating cancer development. 


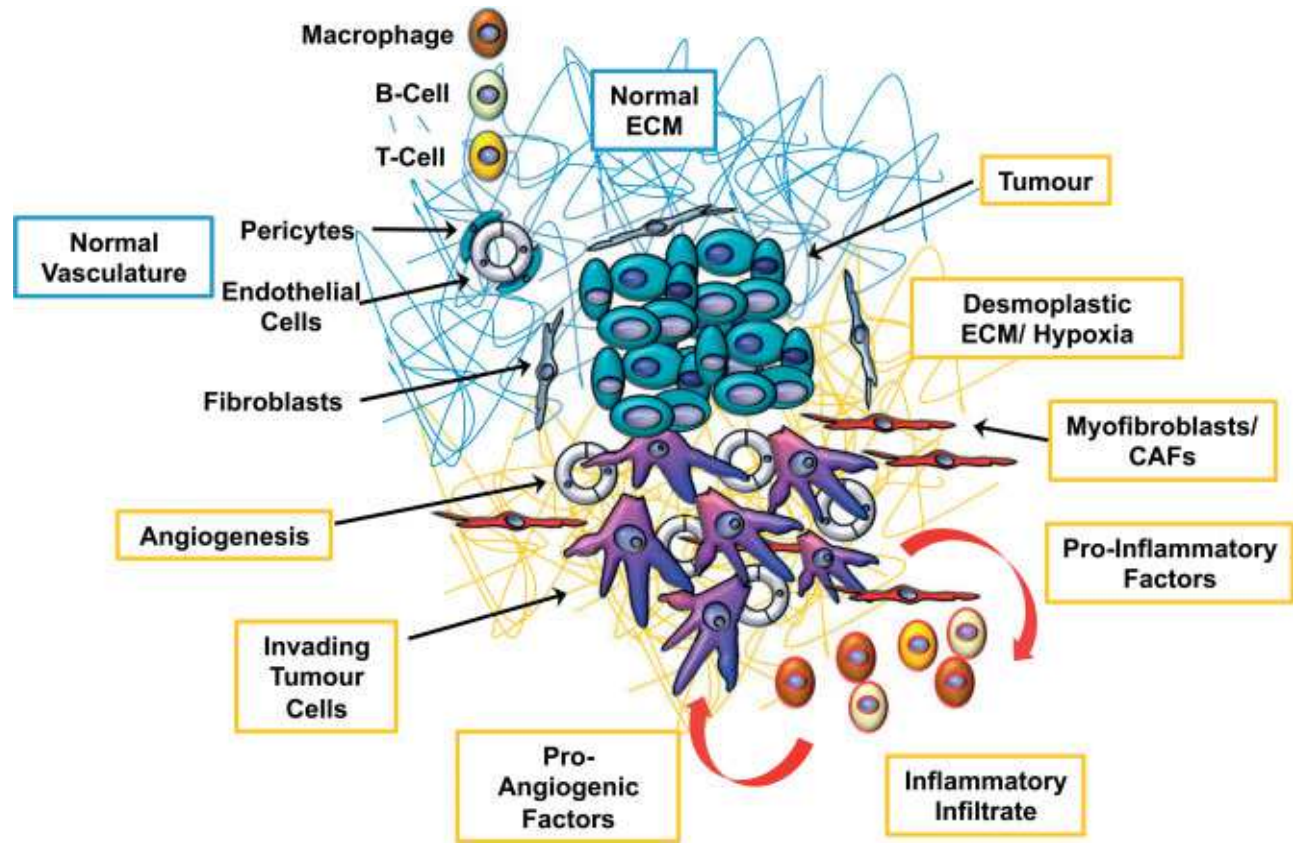

Fig. 1. Representation of the microenvironment alterations in response to tumor growth. Adapted from (Allen \& Louise 2011)

\subsection{Cancer microenvironment and acute phase proteins}

As the tumor microenvironment plays a fundamental role in both the organization of and the escape from anticancer immune responses, the dynamic interplay of the proinflammatory mediators has long supported the notion that inflammation and cancer are interelated. Links between cancer and inflammation were first made in the nineteenth century, on the basis of observations that tumors often arose at sites of chronic inflammation and that inflammatory cells were present in biopsied samples from tumours.(Balkwill \& Mantovani 2001) The idea that these processes are connected was out of favour for more than a century, but there has been a recent resurgence in interest. Several lines of evidence(Balkwill et al 2005;Balkwill \& Mantovani 2001;Coussens \& Werb 2002;Karin 2006) - based on a range of findings, from epidemiological studies of patients to molecular studies of genetically modified mice have led to a general acceptance that inflammation and cancer are linked. General hallmarks of cancer-related inflammation include the presence of inflammatory cells and inflammatory mediators (for example, chemokines, cytokines and prostaglandins) in tumour tissues, tissue remodelling and angiogenesis similar to that seen in chronic inflammatory responses, and tissue repair. These signs of 'smoldering' inflammation (Balkwill, Charles, \& Mantovani 2005;Roxburgh \& McMillan 2010) are also present in tumors for which a firm causal relationship to inflammation has not been established. Indeed, inflammatory cells and mediators are present in the microenvironment of most, if not all, tumors, irrespective of the trigger for development. The cytokines interleukin-6 (IL-6), tumor necrosis factor alpha (TNFa) and interleukin-1 beta (IL-1 $\beta$ ) are critical mediators of the systemic inflammatory response. As a result, these cytokines are 
main stimulators for the synthesis of an acute-phase response. A variety of other modulators may affect APP responses, which include glucocorticoids, insulin and growth factors such as epidermal growth factor, hepatocyte growth factor and transforming growth factor $\beta$. To this effect, the presence of a systemic inflammatory response detected through the measurement of acute-phase reactants is considered a poor prognostic factor for various cancers.

\section{Acute phase proteins in cancer}

A number of well characterized APP have been linked to distinct cancer types and stages of malignancy (See Table 1). C-reactive protein (CRP), serum amyloid A (SAA), $\alpha-1$ glycoprotein (AGP), haptoglobin (HAP), a-1 antichymotrypsin (ACT), and complement proteins represent major positive host response reactants that play different functional roles and have relevance to different types of cancer in humans. The following sections describe compiled data showing support for APPs in distinct human cancers in addition to prognostic significance.

\begin{tabular}{|c|c|c|c|}
\hline APRP & Type of cancer & Response & Method \\
\hline \multirow[t]{10}{*}{ AAT } & Liver cancer & $\uparrow$ & Radial immunodiffusion \\
\hline & Cervical cancer & $\uparrow$ & Immunochemical assay \\
\hline & & & Trypsin inhibitory capacity; immunodiffusion \\
\hline & Colorectal cancer & $\uparrow$ & Immunological methods and nephelometry \\
\hline & Gastric cancer & $\uparrow$ & Immunological method and nephelometry \\
\hline & Lung cancer & $\uparrow$ & Immunological methods \\
\hline & Multiple myeloma & $\uparrow$ & Nephelometry \\
\hline & Ovarian cancer & $\uparrow$ & Radial immunodiffusion \\
\hline & Pancreatic cancer & $\uparrow$ & Radial immunodiffusion \\
\hline & Prostate cancer & $\uparrow$ & Radial immunodiffusion \\
\hline \multirow[t]{4}{*}{$\overline{\mathrm{ACT}}$} & Colorectal cancer & $\uparrow$ & Rocket immunoelectrophoresis \\
\hline & Gastric cancer & $\uparrow$ & Rocket immunoelectrophoresis \\
\hline & Lung cancer & $\uparrow$ & Immunological methods \\
\hline & Pancreatic cancer & $\uparrow$ & Radial immunodiffusion \\
\hline AHS & Liver cancer & $\downarrow$ & Radial immunodiffusion \\
\hline CLU & Urinary bladder cancer & $\uparrow$ & ELISA \\
\hline \multirow[t]{8}{*}{$\mathrm{CPL}$} & Cervical cancer & $\uparrow$ & $\begin{array}{l}\text { Radial immunodiffusion } \\
\text { Nephelometry }\end{array}$ \\
\hline & Chronic lymphocytic leukemia & $\uparrow$ & Nephelometry \\
\hline & Endometrial cancer & $\uparrow$ & Radial immunodiffusion \\
\hline & Gastrointestinal cancer & $\uparrow$ & Immunological methods and nephelometry \\
\hline & Kidney and urinary tract cancer & $\uparrow$ & Radial immunodiffusion \\
\hline & Lung adenocarcinoma & $\uparrow$ & Biochemical assays \\
\hline & Melanoma & $\uparrow$ & Nephelometry \\
\hline & Solid malignant tumors & $\uparrow$ & Nephelometry \\
\hline \multirow[t]{2}{*}{ HAP } & Cervical cancer & $\uparrow$ & Nephelometry \\
\hline & Ovarian cancer & $\uparrow$ & $\begin{array}{l}\text { Immunochemical assay } \\
\text { ELISA }\end{array}$ \\
\hline KNG & Gastrointestinal cancer & $\downarrow$ & Immunochemical assay \\
\hline
\end{tabular}

Table 1. Acute phase protein expression levels in various cancer types [AAT, a1-antitrypsin; ABG, a1-B glycoprotein; ACT, a1-antichymotrypsin; AHS, a2-HS glycoprotein; ATR, Antithrombin III; CFB ,Complement factor B; CLU, Clusterin; CPL, Ceruloplasmin; CRP, Creactive protein; HAP, Haptoglobin; KNG, Kininogen; LRG, Leucine-rich glycoprotein; ZAG, Zinc a2-glycoprotein] Adapted from (Pang et al 2010). 


\subsection{Gastrointestinal (esophagus, stomach, pancreatic, and colorectal) 3.1.1 Esophagus}

Worldwide, esophageal carcinoma affects approximately 480,000 people per year.(Jemal et al 2011) The prognosis of esophageal cancer remains poor. Most patients are still diagnosed with advance stage disease. Advances in neoadjuvant therapy and surgical technique have improved the 5 year survival up to $40-50 \%$ in patients with localized disease. Patients with advanced disease have a 5 year survival of $15 \%$. Accurate staging therefore is essential in patients with esophageal cancer. Many investigators have correlated CRP with esophageal cancer. Acute phase protein levels are thought to reflect the host response to the biological behavior of a tumor. The mean CRP level in patients with esophageal cancer has been found to be elevated compared to patients with benign pathology.(Guillem \& Triboulet 2005) CRP has been shown to be elevated in both adenocarcinoma (AC) and squamous cell carcinoma (SCCA) of the esophagus.(Gockel et al 2006;Nozoe et al 2001;Wang et al 2009) Nozoe et al showed there was no statistical difference in the CRP levels between AC and SCCA.(Nozoe, Saeki, \& Sugimachi 2001) Elevated CRP in both AC and SCCA correlates with tumor depth, lymph node invasion and metastasis.(Gockel, Dirksen, Messow, \& Junginger 2006; Ikeda et al 2003;Nozoe, Saeki, \& Sugimachi 2001;Shimada et al 2003;Wang, Hsieh, Chiu, Li, Huang, Fang, \& Huang 2009) Patients with upper third esophageal cancer have a higher CRP level than patients with middle and lower third cancers.(Wang, Hsieh, Chiu, Li, Huang, Fang, \& Huang 2009) An elevated pretreatment CRP is also associated with decrease survival compared to patients with normal CRP levels(Gockel, Dirksen, Messow, \& Junginger 2006;Ikeda, Natsugoe, Ueno, Baba, \& Aikou 2003;Nozoe, Saeki, \& Sugimachi 2001;Shimada, Nabeya, Okazumi, Matsubara, Shiratori, Aoki, Sugaya, Miyazawa, Hayashi, Miyazaki, \& Ochiai 2003;Wang, Hsieh, Chiu, Li, Huang, Fang, \& Huang 2009;Zingg et al 2010). Zingg et al showed that an elevated serum CRP level independent prognostic indicator for survival in patients with esophageal cancer. In patients that underwent neoadjuvant therapy followed by esophagectomy, patients with normal CRP levels had a significant survival advantage compared to patient with an elevated CRP (median survival 65.4 moths and 5year survival $52.1 \%$ compared to median survival 18.7 months vs 5 -year survival $23.3 \%$, $\mathrm{p}=0.027$ ).(Zingg, Forberger, Rajcic, Langton, \& Jamieson 2010) Data for other acute phase proteins in esophageal cancer is limited. An et al showed in a small study that SAA and HAP were elevated in patients with esophageal cancer.(An et al 2004)

\subsubsection{Stomach}

Worldwide, an estimated total of 989,600 new stomach cancer cases and 738,000 deaths are estimated to have occurred in 2008. Over $70 \%$ of new cases and deaths occur in developing countries. (Jemal, Bray, Center, Ferlay, Ward, \& Forman 2011) The prognosis for gastric cancer is poor because of advanced disease at diagnosis. (Collard et al 2003) To improve the poor survival outcome and help identify earlier diagnosis, there is a need for new and more sensitive biomarkers.

CRP has been shown to be elevated in patients with gastric cancer compared to healthy controls. (Ilhan et al 2004;Kim et al 2009;Lukaszewicz-Zajac et al 2010;Tsavaris et al 2005) Elevated CRP (>3mg/L) is associated with infiltrative type, larger tumors, serosal invasion, lymph node metastasis, distant metastasis. (Chang et al 2010;Kim, Oh, Kwon, Lee, Kwon, Kim, Kim, Kim, Jang, Kim, Kim, Han, \& Kim 2009;Lukaszewicz-Zajac, Mroczko, Gryko, Kedra, \& Szmitkowski 2010) Chang et al showed that 5-year survival rate of patients with an 
elevated CRP was significantly worse than those without $(<3.0 \mathrm{mg} / \mathrm{L})$. (Chang, Sun, Pai, Wang, Hsieh, Kuo, \& Wang 2010)

SAA has been shown to be elevated in gastric cancer. Elevated SAA was associated with tumor size, depth of tumor, lymph node metastasis, and tumor location.(Chan et al 2007; Chang, Sun, Pai, Wang, Hsieh, Kuo, \& Wang 2010) Chang et al showed that SAA increased $2.10 \mathrm{mg} / \mathrm{L}$ for each $1 \mathrm{~mm}$ increase in tumor size and SAA concentration was higher in patients with tumors located in the upper portion of the stomach compared to the lower stomach. SAA was also elevated in patients with recurrent cancer compared to those who did not recur.

AAT has been reported to be elevated in patients with gastric cancer compared to healthy controls. There has not been any correlation with an elevated AAT and disease status or patient outcome. Several reports have corroborated elevated levels of AAT in gastric juice in patients with gastric cancer compared with healthy controls. (Hsu et al 2007; Lee et al 2004)

\subsubsection{Pancreas}

Pancreatic cancer is the fourth most common cause of cancer-related death in the United States. The five-year survival is about $4 \%$, which is the lowest among all cancers. The high mortality rate is due to patients presenting with advanced stage of the disease due to the early aggressiveness of this cancer, the inability to diagnose it early and the currently lack of effective therapies. Surgical resection is the only potentially curative treatment for pancreatic cancer. Only $10-20 \%$ of patients diagnosed with pancreatic cancer are able to undergo surgical resection due to advanced presentation at diagnosis. Advances are needed to help accurately detect pancreatic cancer early in its disease process.

Circulating levels of CRP have been found to be significantly elevated in patients with pancreatic cancer compared to healthy controls.(Mroczko et al 2010;Orchekowski et al 2005) There was a significant increase in CRP levels with more advanced stages of pancreatic cancer. Patients with an elevated pre-operative CRP level were found at surgery to have an increase in tumor size, vascular invasion, and poor differentiated tumors.(Jamieson et al 2005) Serum levels of CRP have been found to be independent predictor of survival in both patients with resectable pancreatic adenocarcinoma and metastatic disease.(Falconer et al 1995;Jamieson, Glen, McMillan, McKay, Foulis, Carter, \& Imrie 2005;Pine et al 2009;Tingstedt et al 2007) Falconer et al in a respective review of 102 patients with unresectable pancreatic cancer found the presence of an acute-phase response to be the most significant independent predictor of survival duration.(Falconer, Fearon, Ross, Elton, Wigmore, Garden, \& Carter 1995) The median survival of those was an acute-phase response was 66 days compared to 222 days for those with no acute phase response.

Other APP, SAA, AAT, APE, and HAP have been reported as being elevated in patients with pancreatic cancer but the correlation with tumor pathology and survival data is lacking.(Deng et al 2007;Firpo et al 2009;Koomen et al 2005;Orchekowski, Hamelinck, Li, Gliwa, vanBrocklin, Marrero, Vande Woude, Feng, Brand, \& Haab 2005; Trichopoulos et al 1990; Yu et al 2005) Firpo et al demonstrated that HPT and SAA were both elevated in patients with pancreatic cancer compared to healthy controls and patients with other benign pancreatic diseases. The addition of HAP and SAA improved detection of pancreatic cancer when they were added to a screening panel.(Firpo, Gay, Granger, Scaife, DiSario, Boucher, \& Mulvihill 2009) Trichopoulos et al demonstrated that patients with an elevated AAT at the time of diagnosis had a significantly shorter survival. 


\subsubsection{Colorectal}

Yearly, there are approximately 1.2 million new colorectal cancer cases and 608,700 deaths are estimated to occur. (Jemal, Bray, Center, Ferlay, Ward, \& Forman 2011) Colorectal cancer is curable if detected early. New methods are needed to help detect colorectal cancer and patients that are at high risk for developing metastatic disease and reoccurrence.

The association of serum CRP levels with risk of colorectal cancer has been examined in several prospective studies. The results of these studies have been inconsistent. (Aleksandrova et al 2010;Erlinger et al 2004;Gunter et al 2006; Ito et al 2005;Zhang et al 2005) In several prospective studies, patients with an elevated baseline CRP were at a higher risk for developing colon cancer compared to rectal cancer.(Aleksandrova, Jenab, Boeing, Jansen, Bueno-de-Mesquita, Rinaldi, Riboli, Overvad, Dahm, Olsen, Tjonneland, Boutron-Ruault, Clavel-Chapelon, Morois, Palli, Krogh, Tumino, Vineis, Panico, Kaaks, Rohrmann, Trichopoulou, Lagiou, Trichopoulos, van Duijnhoven, Leufkens, Peeters, Rodriguez, Bonet, Sanchez, Dorronsoro, Navarro, Barricarte, Palmqvist, Hallmans, Khaw, Wareham, Allen, Spencer, Romaguera, Norat, \& Pischon 2010;Erlinger, Platz, Rifai, \& Helzlsouer 2004;Gunter, Stolzenberg-Solomon, Cross, Leitzmann, Weinstein, Wood, Virtamo, Taylor, Albanes, \& Sinha 2006) In these studies, persons in the highest quartile of CRP concentration had greater than a 3-fold increase risk of developing colon cancer compared with those in the lowest quartile. Erlinger et al found persons who subsequently developed colon cancer, the median CRP was 2.69 vs $1.97 \mathrm{mg} / \mathrm{L}$ for matched controls $(\mathrm{P}<.001)$.(Erlinger, Platz, Rifai, \& Helzlsouer 2004) CRP has been shown to be elevated in patients with colorectal cancer compared to controls.(Aleksandrova, Jenab, Boeing, Jansen, Bueno-de-Mesquita, Rinaldi, Riboli, Overvad, Dahm, Olsen, Tjonneland, Boutron-Ruault, Clavel-Chapelon, Morois, Palli, Krogh, Tumino, Vineis, Panico, Kaaks, Rohrmann, Trichopoulou, Lagiou, Trichopoulos, van Duijnhoven, Leufkens, Peeters, Rodriguez, Bonet, Sanchez, Dorronsoro, Navarro, Barricarte, Palmqvist, Hallmans, Khaw, Wareham, Allen, Spencer, Romaguera, Norat, \& Pischon 2010;Kaminska et al 2000;Kemik et al 2010) Elevated CRP concentrations are associated with tumor length, poorly differinated histology, tumor depth, lymph node metastasis, liver metastases, and Duke's stage.(Nozoe et al 1998;Nozoe et al 2008) There has been controversy as to an elevated CRP is an independent prognostic indicator.(Chung \& Chang 2003; McMillan et al 2003;Nielsen et al 2000;Nozoe, Mori, Takahashi, \& Ezaki 2008;Simpson et al 1995) Nozoe et al showed the 5-year survival rates in patients with elevated CRP levels was $28.8 \%$ compared to $94.3 \%$ in patients with normal CRP levels.(Nozoe, Mori, Takahashi, \& Ezaki 2008)

SAA has been found to be elevated in patient with colorectal cancer compared to healthy controls.(Glojnaric et al 2001) Glojnaric et al showed that mean pre-operative SAA concentration was $38 \mathrm{mg} / 1$ in patients with Dukes stage B and C colorectal carcinoma. SAA concentrations have been shown to increase with advanced stage in colorectal cancer.(Biran et al 1986) Several studies have shown that patients with colorectal cancer have higher levels of circulating HAP and AAT.(Park et al 2010;Ward et al 1977) Patients that developed recurrence within 2 years or developed hepatic metastases had elevated HPT and AAT.(Ward, Cooper, Turner, Anderson, \& Neville 1977)

\subsection{Lung}

In 2008, lung cancer was the most commonly diagnosed cancer and the leading cause of cancer death in males. In females, it is the fourth most diagnosed cancer and the second leading cause of cancer death. (Jemal, Bray, Center, Ferlay, Ward, \& Forman 2011) The 
expected 5-year survival for all patients diagnosed with lung cancer is $15 \%$. Surgical resection of non-small cell lung cancer (NSCLC) offers the potential for cure, but there is often difficulty in selecting suitable patients for surgical resection. Newer approaches are needed to aid in earlier diagnosis.

The Rotterdam Study (Siemes et al 2006) found that high levels ( $>3 \mathrm{mg} / \mathrm{L}$ ) of CRP were associated with an increased incidence of lung cancer. There was an age-, sex-, and smokingadjusted hazard ratio for incident lung cancer of 2.8 when CRP levels were elevated. After the 5-year latent period, the hazard ratio was reduced to a 2.1 fold risk increase. Elevated pre-operative CRP levels have been found to be an independent and significant prognostic indicator in patients with NSCLC. Elevated pre-operative CPR level is associated with increase maximum pathologic tumor size, lymphovascular invasion, and inability to achieve complete resection in patients with NSCLC.(Hara et al 2007; Jones et al 2006; Lee et al 2009) Disease specific survival and overall survival were significantly decreased in patients with elevated pre-operative CRP compared to non-elevated CRP patients, which is independent of TNM stage. (Hara, Matsuzaki, Shimuzu, Tomita, Ayabe, Enomoto, \& Onitsuka 2007; O'Dowd et al 2010)

SAA was found to be higher in patients in patients with NSCLC compared to healthy controls.(Benson et al 1986;Dowling et al 2007;Gao et al 2005;Howard et al 2003;Liu et al 2007) Howard BA et al found SAA to elevated at $286 \mathrm{ng} / \mathrm{mL}$ in serum of lung cancer patients compared to $34.1 \mathrm{ng} / \mathrm{mL}$ in serum of control patients. Elevated levels of SAA correlated with increase in the clinical stages I-IV and were higher in patients with squamous cell carcinoma.(Liu, Wang, Zhang, Dai, Liu, Liu, Wu, Yang, Fu, Xiao, \& He 2007) SAA has been shown to be a prognostic biomarker. Patients with a survival $\geq 5$ years had a significantly lower SAA than patients with a survival $<5$ years.(Cho et al 2010)

Circulating levels of HAP has been shown to be elevated as high as three-fold in patients with SCLC compared to healthy controls.(Bharti et al 2004;Dowling, O'Driscoll, Meleady, Henry, Roy, Ballot, Moriarty, Crown, \& Clynes 2007) Bharti et al showed a tendency of increased survival when HAP was <1.9. AAT and apolipoprotein A-1 (ApoA-1) have been also shown to be elevated in lung cancer compared to healthy controls. (Dowling, O'Driscoll, Meleady, Henry, Roy, Ballot, Moriarty, Crown, \& Clynes 2007;Gao, Kuick, Orchekowski, Misek, Qiu, Greenberg, Rom, Brenner, Omenn, Haab, \& Hanash 2005)

\subsection{Melanoma}

Malignant melanoma is a cutaneous neoplasm known for its highly aggressiveness, early dissemination, and poor prognosis once metastasized. It is estimated that 68,130 cases of invasive malignant melanoma and at least 48,000 cases of melanoma in-situ will be diagnosed in the US this year. (Rigel 2010) Numerous biomarkers help determine exist to help determine the prognosis of patients with distant metastases; S100B and lactate dehydrogenase (LDH )are the most widely distributed clinical markers, yet these fail to predict disease progression, relapse or metastasis in early-stage melanoma.(Findeisen et al 2009)

CRP levels have been found to be elevated in all stages of melanoma. High levels of circulating CRP has been associated with a reduced overall survival in early disease stages (stage I to III) and late stage (stage IV).(Findeisen, Zapatka, Peccerella, Matzk, Neumaier, Schadendorf, \& Ugurel 2009) Circulating levels of CRP correlate with clinical response to interleukin-2 (IL-2) based immunotherapy. (Tartour et al 1994) Tartour et al found patients with CRP levels $>10$ has a poor clinical response to IL-2 therapy and poor survival compared to patients with lower CRP levels. In a prospective study by Deichman et al, CRP 
was significantly elevated in stage IV melanoma patients compared to stage I to stage III, whereas LDH was not. (Deichmann et al 2004) They concluded that LDH provided no additional information to CRP.

Circulating levels of SAA was found to be prognositic in melanoma patients.(Findeisen, Zapatka, Peccerella, Matzk, Neumaier, Schadendorf, \& Ugurel 2009) SAA levels less than $10 \mathrm{mg} / \mathrm{mL}$ showed favorable survival complared to patients with high serum levels. SAA levels were prognostic when patients were analyzed separately in stage I-III and stage IV. ACT has been shown to be elevated in metastatic melanoma. Patients with stage III melanoma with low ACT levels, survived 43.4 months compared to 18.5 months in patients with high levels of ACT, $p=0.048$ ).(Wang et al 2010) Similar results were seen with stage IV disease.

\subsection{Renal cell}

Renal cell carcinoma (RCC) is difficult to diagnose due to lack of clinical symptoms. Approximately $40 \%$ of patients with RCC have a metastasis at the time of diagnosis and approximately $25-30 \%$ of patients will develop metastatic tumors within 5 years after nephrectomy.(Cohen \& McGovern 2005) Metastatic RCC has a poor prognosis with a median overall survival of about 1 year.(Bleumer et al 2003) The need for reliable markers for diagnosis and follow-up of RCC remains.

CRP has been shown to be elevated in patients with localized and metastatic RCC. (Casamassima et al 2005;Cho et al 2011;Ito et al 2006;Jagdev et al 2010;Komai et al 2007;Saito et al 2009) Patients with localized RCC and elevated CRP levels have been found to have larger tumors, higher percentages of lymph node metastasis, higher histological grade and higher percentages of microvascular invasion.(Cho, Kim, Lee, Ahn, Kim, \& Kim 2011;Ito, Asano, Yoshii, Satoh, Sumitomo, \& Hayakawa 2006;Komai, Saito, Sakai, \& Morimoto 2007) Elevated circulating levels of CRP have been shown to be independent factor of disease specific survival (DSS) and recurrence free survival (RFS).(Cho, Kim, Lee, Ahn, Kim, \& Kim 2011;Ito, Asano, Yoshii, Satoh, Sumitomo, \& Hayakawa 2006;Jagdev, Gregory, Vasudev, Harnden, Sim, Thompson, Cartledge, Selby, \& Banks 2010;Komai, Saito, Sakai, \& Morimoto 2007) Komai $Y$ et al showed the 5- and 10-year DSS rates with patients with elevated CRP were $75 \%$ and $30 \%$ compared to both $93 \%$ in patients with normal CRP $(p<0.001)$ Circulating levels of CRP have been shown to be elevated in patients with metastatic RCC and predictive of overall survival.(Casamassima, Picciariello, Quaranta, Berardino, Ranieri, Paradiso, Lorusso, \& Guida 2005;Saito, Tatokoro, Fujii, Iimura, Koga, Kawakami, \& Kihara 2009) Saito et al showed overall survival was significantly different in patients with elevated CRP levels who did not normalize while on treatment. Patients with metastatic non-elevated CRP levels had a 2 -year survival of $69 \%$ compared to $4 \%$ in patients with elevated CRP that did not normalize.

Circulating levels of SAA has been shown to be elevated in patients with RCC.(Engwegen et al 2007;Kimura et al 2001;Ramankulov et al 2008;Tolson et al 2004;Wood et al 2010) Elevated levels of SAA correlated with increased tumor stage, tumor grade, and metastasis.(Kimura, Tomita, Imai, Saito, Katagiri, Ohara-Mikami, Matsudo, \& Takahashi 2001;Ramankulov, Lein, Johannsen, Schrader, Miller, Loening, \& Jung 2008) In relation to histological features, median SAA concentration in clear cell, papillary and chromophobe subtypes were not statistically different.(Ramankulov, Lein, Johannsen, Schrader, Miller, Loening, \& Jung 2008) 
SAA concentrations have been shown to be an independent prognostic factor for outcome in patients with RCC. Patient with high circulating levels of SAA had shorter survival times compared to patients with non-elevated SAA.(Kimura, Tomita, Imai, Saito, Katagiri, OharaMikami, Matsudo, \& Takahashi 2001;Ramankulov, Lein, Johannsen, Schrader, Miller, Loening, \& Jung 2008; Wood, Rogers, Cairns, Paul, Thompson, Vasudev, Selby, \& Banks 2010)

\subsection{Ovarian}

Worldwide, there is approximately 225,000 new cases of ovarian cancer diagnosed yearly.(Jemal, Bray, Center, Ferlay, Ward, \& Forman 2011) The 5-year survival for patients with early-stage ovarian cancer is approximately $95 \%$, but it is $25 \%$ for advanced-stage disease. In $80 \%$ of patients with ovarian cancer, the disease is already advanced at the time of initial diagnosis. This highlights the need for early diagnosis to decrease the morbidity and mortality of ovarian cancer.

Ovarian cancer risk is positively associated with increasing serum levels of CRP concentration.(McSorley et al 2007) In a multicenter, nested, case-control study, McSorley et al found a significant increased risk of developing ovarian cancer with increasing serum CRP levels. There was a two -fold risk of developing ovarian cancer was observed among women with CRP levels within a range of 3 to $10 \mathrm{mg} / \mathrm{L}$, as compared to women with CRP levels less than $1 \mathrm{mg} / \mathrm{L}$. CRP has been shown to be significantly elevated in patients with ovarian cancer.(Bertenshaw et al 2008;Edgell et al 2010;Hefler et al 2008;Hefler-Frischmuth et al 2009;Kodama et al 1999;Maccio et al 1998) Circulating levels of CRP have been shown to correlate with International Federation of Gynecologists and Obstetricians stage (FIGO), post-operative residual tumor.(Hefler, Concin, Hofstetter, Marth, Mustea, Sehouli, Zeillinger, Leipold, Lass, Grimm, Tempfer, \& Reinthaller 2008;Hefler-Frischmuth, Hefler, Heinze, Paseka, Grimm, \& Tempfer 2009) Hefler et al demonstrated patients with platinumresistant epithelial ovarian cancer (EOC) had a significantly higher CRP serum levels compared with patients with platinum-sensitive EOC. Elevated serum CRP is a significant prognostic factor in patients with EOC. Hefler et al found women with an elevated CRP $(>1 \mathrm{mg} / \mathrm{L})$ had a 5 -year overall survival of $58.5 \%$ versus $82 \%$ in women with normal CRP $(<1 \mathrm{mg} / \mathrm{L})$.

Several other AAP have been reported to be elevated in ovarian cancer, but the correlation with tumor stage and prognosis is lacking. SAA has been shown to be elevated in patients with ovarian cancer.(Edgell, Martin-Roussety, Barker, Autelitano, Allen, Grant, \& Rice 2010;Helleman et al 2008; Moshkovskii et al 2007a;Moshkovskii et al 2007b) Edgell et al found the mean SAA in patients with ovarian cancer to be $113 \mathrm{ng} / \mathrm{mL}$ compared to $5 \mathrm{ng} / \mathrm{mL}$ in healthy controls. HAP has been demonstrated to be elevated in patients with ovarian cancer.(Bertenshaw, Yip, Seshaiah, Zhao, Chen, Wiggins, Mapes, \& Mansfield 2008; Ye et al 2003) Bertenshaw et al found AAT to be elevated in patients with ovarian cancer compared to controls.(Bertenshaw, Yip, Seshaiah, Zhao, Chen, Wiggins, Mapes, \& Mansfield 2008)

Circulating levels of ApoA-1 has been shown to be decreased compared to healthy controls.(Bertenshaw, Yip, Seshaiah, Zhao, Chen, Wiggins, Mapes, \& Mansfield 2008;Nosov et al 2009; Su et al 2007; Zhang et al 2004) Nosov V et al demonstrated that patients with late stage ovarian cancer had an ApoA-1 level of $88.10 \mathrm{mg} / \mathrm{dL}$ compared to $154.36 \mathrm{mg} / \mathrm{dL}$ for healthy controls. 


\subsection{Breast}

Worldwide breast cancer is the most frequently diagnosed cancer among women and the leading cause of cancer death in females. In 2008, breast cancer accounted for 1.38 million $(23 \%)$ o the total new cancer cases and 458,000 (14\%) of the total cancer deaths in females.(Jemal, Bray, Center, Ferlay, Ward, \& Forman 2011) Chronic inflammation has been shown to contribute to breast cancer development and progression. Chronic inflammation promotes mammary tumor development through mechanisms involving chronic activation of humoral immunity and infiltration of Th2 cells and polarized innate inflammatory cells.(DeNardo \& Coussens 2007) Inflammatory status is suggested to be a prognostic factor for breast cancer.

The association between circulating concentrations of CRP levels have been widely analyzed. There is conflicting reports between baseline levels of CRP and developing breast cancer. Rotterdam Study reported a $28 \%$ increase in breast cancer risk was associated with 1unit increase of CRP levels above baseline.(Siemes, Visser, Coebergh, Splinter, Witteman, Uitterlinden, Hofman, Pols, \& Stricker 2006) There was no statistically significantly associated breast cancer risk in studies conducted by $\mathrm{Il}^{\prime}$ yasova et al and Trichopoulos et al.(Il'yasova et al 2005;Trichopoulos et al 2006) Results from studies assessing the association of NSAIDs and statins, which are also known to lower CRP levels, and breast cancer risk have also been mixed. The circulating levels of CRP have been found to be higher in patients with breast carcinoma compared to healthy controls. (O'Hanlon et al 2002) Significant increases in circulating levels of CRP correlate with increase tumor size, lymph node involvement and distant metastasis. As the stage of the disease increased, CRP levels increased proportionally. (O'Hanlon, Lynch, Cormican, \& Given 2002;Ravishankaran \& R K 2011) Results from several studies have shown an association between CRP and survival in patients with metastatic disease.(Al Murri et al 2007;Albuquerque et al 1995;Pierce et al 2009) Pierce et al also found that elevated CRP levels were associated with reduced diseasefree survival.(Pierce, Ballard-Barbash, Bernstein, Baumgartner, Neuhouser, Wener, Baumgartner, Gilliland, Sorensen, McTiernan, \& Ulrich 2009)

\subsection{Neuroblastoma}

Neuroblastoma (NB) is the most common extracranial solid tumor of childhood. Despite treatment which may involve multimodality approaches, children with high-risk disease still have an overall survival rate of less than $40 \%$ despite multi-modality therapy.(Maris et al 2007) This highlights the need for earlier detection of advanced stage NB.

While limited in number, studies have corroborated circulating levels of several acute phase proteins to be elevated in children with NB. Serum concentrations of apolipoprotein A-IV (ApoA-IV), HAP, AAT and SAA have been shown to be elevated in children with NB compared to healthy controls.(Combaret et al 2005;Gerson et al 1977;Lipinska et al 1992;Sandoval et al 2007) Work from our laboratory demonstrated that ApoA-IV, HAP, and SAA were increased in patients with advanced stage neuroblastoma compared to healthy controls (Sandoval et al 2007). Others have shown CRP, HP and AAT were higher in patients with poor prognosis patient compared to good prognosis patients (Lipinska et al1992). Finally, work by Gerson et al demonstrated the APP response returned to normal in all patients that responded to treatment by surgery, radiation and chemotherapy, but rose again with recurrence of disease. These studies support the notion of an inflammatory response to the tumor maybe detected and potentially used as complementary cancer markers. 


\section{Profiling acute phase proteins}

Advances in proteomics technologies have provided an important tool that can systematically identify and quantify steady-state or perturbation-induced changes in a complex biological system in a high throughput fashion. There has been a great interest in applying this technology to cancer biomarker discovery. Yet the clinical translation of proteomic technology and bioinformatics tools to human samples, such as in the area of cancer biomarkers, represents one of the major opportunities and challenges facing this field. An ongoing challenge in proteomics continues to be the analysis of the serum proteome due to the vast number and complexity of proteins estimated to be present in this biofluid. The enormous diversity in protein species and post-translational modifications of proteins, and the vast differences in protein abundance, create major challenges, as well as a great opportunity, in employing quantitative plasma proteomics for biomarker discovery. Nonetheless, an active area of interest includes enrichment strategies for optimal biomarker candidates from serum and plasma.

As proteomics aims for the full identification and quantification of all expressed proteins, profiling strategies usually are applied on sub-sets of the proteome. The expression of serum proteins can be analyzed concurrently by using the gel-based proteomic technology. This is appropriate for studying the acute-phase response, which involves the simultaneous altered expression of serum proteins in association to inflammation, infection, injury or cancer. Many proteomic studies on serum or plasma have been performed using samples that were depleted of albumin and/or immunoglobulins in order to analyze serum proteins of lower abundance. However, a number of serum proteins including those that have been used clinically or experimentally have been demonstrated to adhere strongly to albumin and immunoglobulins. These serum proteins were also removed in experiments involving depletion of the high abundance proteins, and thus, may affect interpretation of the results. Moreover, recent studies using rat plasma have revealed that depletion of high abundance proteins only reduced the dynamic range of plasma proteome by two to three orders of magnitude. Removal of albumin, IgG, IgM, transferrin, fibrinogen, HAP and AAT from rat plasma leads to the unmasking of only a few proteins and was still far from being able to detect the low abundance proteins (Linke et al 2007). Given these barriers, applied approaches to simplify and increase the depth of serum proteomic analysis include fractionation strategies, targeted protein subpopulation enrichment (phosphoproteins, glycoproteins, etc.), and differential quantifying protein methods such as isobaric tags for relative and absolute quantification (iTRAQ). In addition, other novel work in biomarker discovery involves proximal fluid proteomics. (Teng et al 2010) Proximal fluid, the fluid derived from the extracellular milieu of tissues, contains a large repertoire of shed and secreted proteins that are likely to be present at higher concentrations relative to plasma/serum. It has been hypothesized that many, if not all, proximal fluid proteins exchange with peripheral circulation, which has provided significant motivation for utilizing proximal fluids as a primary sample source for protein biomarker discovery. Finally, opportunities in the exploration of the nano-scale open new strategies for serum protein analysis. For example, Pujia and colleagues recently described a tool based on biodegradable nanoporous nanoparticles (NPNPs) that allows the harvesting of lowmolecular-weight fractions of crude human serum/plasma. (Pujia et al 2010) NPNPs with a diameter of $200 \mathrm{~nm}$ and pore size of a few $\mathrm{nm}$ were obtained by ultrasonication of nanoporous silicon. When incubated with a solution, the NPNPs harvest only the molecules 
small enough to be absorbed into the nanopores. These in turn can be recovered by centrifugation and dissolved in water, making the harvested molecules available for further analyses. The development and utilization of novel methods in serum APP biomarker discovery may include novel strategies including nanostructured materials and other high throughput methods like protein arrays, multiplexed protein assays, and chip-based proteomic platforms.

\section{Acute phase proteins as biomarkers}

Blood-based protein biomarkers have been used in clinical laboratories for decades to aid in the diagnosis and prognosis of many diseases, including a variety of cancers. As shown in this chapter, circulating levels of APPs have been confirmed to coincide in patients with many solid malignancies. However, these acute phase reactants are not specific for cancer, and these serum APP concentrations need to be interpreted in the context of a full clinical examination and the presence of other signs and symptoms of malignancy. Nevertheless, an ongoing emerging theme clearly supports the role of a bidirectional tumor-host response and the ensuing concept of inflammation as a biomarker for cancer.

While the analysis of the serum proteome has challenges, we envision contemporary serum proteomics studies using high-throughput proteomic methodologies and bioinformatics will enable the identification of a subset of acute phase protein markers for the unequivocal discrimination of malignancy. While many of these APP are found within the inflammatory cascade, an important distinctive feature may include protein glycosylation. Glycosylationrelated changes represent one of the major post translational modifications and can have significant effects on protein function. Moreover, changes in the carbohydrate structure are increasingly being recognized as an important modification associated with cancer. (Hakomori 1996;Hakomori 2002) These differences can be further explored using techniques such as microarray platform to characterize glycan structure and to study glycosylationrelated biological interactions using probes as a means to interrogate the spotted or captured glycosylated molecules on the arrays. The high-throughput and reproducible nature of the microarray platforms allow simultaneous assessment of a number of defined proteins on a single platform. For instance, Zeng et al using an integrated system based on multiple lectin affinity chromatography (M-LAC) that partions serum proteins based on glycan characteristics, found proteins such as ABG, complement C3, ATT, and transferrin accurately identified patients with breast cancer. As the field of inflammatory biomarkers continues to evolve, we feel the host immune response can be further exploited to better integrate these APPs into the design of personalized biomarkers for the noninvasive diagnosis of cancer. (Zeng et al 2010)

\section{Conclusions}

Inflammation appears to play a dominant role in the pathogenesis of various cancer types. This review has focused on the current understanding of the dynamic role of the host-tumor interaction with regards to inflammation and the developing field of acute phase reactants as circulating cancer biomarkers. The field of acute phase proteins as cancer biomarkers has tremendous potential. The identification of specific proteomic expression patterns in acute phase proteins related to cancer as well as a more thorough understanding of this proinflammatory response in tumor pathogenesis offers promise not only for novel 
molecular diagnostic markers but also for new therapy strategies in the treatment of solid malignancies.

\section{Acknowledgements}

The authors of this chapter wish to acknowledge Mrs. Gailya Taylor for her assistance in the preparation of this work.

\section{References}

Al Murri,A.M., Wilson,C., Lannigan,A., Doughty,J.C., Angerson,W.J., McArdle,C.S., \& McMillan,D.C. (2007) Evaluation of the relationship between the systemic inflammatory response and cancer-specific survival in patients with primary operable breast cancer. Br.J.Cancer 96, 891-895.

Albuquerque,K.V., Price,M.R., Badley,R.A., Jonrup,I., Pearson,D., Blamey,R.W., \& Robertson,J.F. (1995) Pre-treatment serum levels of tumour markers in metastatic breast cancer: a prospective assessment of their role in predicting response to therapy and survival. Eur.J.Surg.Oncol. 21, 504-509.

Aleksandrova,K., Jenab,M., Boeing,H., Jansen,E., Bueno-de-Mesquita,H.B., Rinaldi,S., Riboli,E., Overvad,K., Dahm,C.C., Olsen,A., Tjonneland,A., Boutron-Ruault,M.C., Clavel-Chapelon,F., Morois,S., Palli,D., Krogh,V., Tumino,R., Vineis,P., Panico,S., Kaaks,R., Rohrmann,S., Trichopoulou,A., Lagiou,P., Trichopoulos,D., van Duijnhoven,F.J., Leufkens,A.M., Peeters,P.H., Rodriguez,L., Bonet,C., Sanchez,M.J., Dorronsoro,M., Navarro,C., Barricarte,A., Palmqvist,R., Hallmans,G., Khaw,K.T., Wareham,N., Allen,N.E., Spencer,E., Romaguera,D., Norat,T., \& Pischon,T. (2010) Circulating C-reactive protein concentrations and risks of colon and rectal cancer: a nested case-control study within the European Prospective Investigation into Cancer and Nutrition. Am.J.Epidemiol. 172, 407-418.

Allen,M. \& Louise,J.J. (2011) Jekyll and Hyde: the role of the microenvironment on the progression of cancer. J Pathol 223, 162-176.

An,J.Y., Fan,Z.M., Zhuang,Z.H., Qin,Y.R., Gao,S.S., Li,J.L., \& Wang,L.D. (2004) Proteomic analysis of blood level of proteins before and after operation in patients with esophageal squamous cell carcinoma at high-incidence area in Henan Province. World J.Gastroenterol. 10, 3365-3368.

Balkwill,F., Charles,K.A., \& Mantovani,A. (2005) Smoldering and polarized inflammation in the initiation and promotion of malignant disease. Cancer Cell 7, 211-217.

Balkwill,F. \& Mantovani,A. (2001) Inflammation and cancer: back to Virchow? Lancet 357, 539-545.

Benson,M.D., Eyanson,S., \& Fineberg,N.S. (1986) Serum amyloid A in carcinoma of the lung. Cancer 57, 1783-1787.

Bertenshaw,G.P., Yip,P., Seshaiah,P., Zhao,J., Chen,T.H., Wiggins,W.S., Mapes,J.P., \& Mansfield,B.C. (2008) Multianalyte profiling of serum antigens and autoimmune and infectious disease molecules to identify biomarkers dysregulated in epithelial ovarian cancer. Cancer Epidemiol.Biomarkers Prev. 17, 2872-2881.

Bharti,A., Ma,P.C., Maulik,G., Singh,R., Khan,E., Skarin,A.T., \& Salgia,R. (2004) Haptoglobin alpha-subunit and hepatocyte growth factor can potentially serve as serum tumor biomarkers in small cell lung cancer. Anticancer Res. 24, 1031-1038. 
Biran,H., Friedman,N., Neumann,L., Pras,M., \& Shainkin-Kestenbaum,R. (1986) Serum amyloid A (SAA) variations in patients with cancer: correlation with disease activity, stage, primary site, and prognosis. J.Clin.Pathol. 39, 794-797.

Bleumer,I., Oosterwijk,E., De,M.P., \& Mulders,P.F. (2003) Immunotherapy for renal cell carcinoma. Eur.Urol. 44, 65-75.

Casamassima,A., Picciariello,M., Quaranta,M., Berardino,R., Ranieri,C., Paradiso,A., Lorusso,V., \& Guida,M. (2005) C-reactive protein: a biomarker of survival in patients with metastatic renal cell carcinoma treated with subcutaneous interleukin-2 based immunotherapy. J.Urol. 173, 52-55.

Chan,D.C., Chen,C.J., Chu,H.C., Chang,W.K., Yu,J.C., Chen,Y.J., Wen,L.L., Huang,S.C., Ku,C.H., Liu,Y.C., \& Chen,J.H. (2007) Evaluation of serum amyloid A as a biomarker for gastric cancer. Ann.Surg.Oncol. 14, 84-93.

Chang,C.C., Sun,C.F., Pai,H.J., Wang,W.K., Hsieh,C.C., Kuo,L.M., \& Wang,C.S. (2010) Preoperative serum C-reactive protein and gastric cancer; clinical-pathological correlation and prognostic significance. Chang Gung.Med.J. 33, 301-312.

Cho,D.S., Kim,S.J., Lee,S.H., Ahn,H.S., Kim,Y.S., \& Kim,S.I. (2011) Prognostic significance of preoperative C-reactive protein elevation and thrombocytosis in patients with nonmetastatic renal cell carcinoma. Korean J.Urol. 52, 104-109.

Cho,W.C., Yip,T.T., Cheng,W.W., \& Au,J.S. (2010) Serum amyloid A is elevated in the serum of lung cancer patients with poor prognosis. Br.J.Cancer 102, 1731-1735.

Chung,Y.C. \& Chang,Y.F. (2003) Significance of inflammatory cytokines in the progression of colorectal cancer. Hepatogastroenterology 50, 1910-1913.

Cohen,H.T. \& McGovern,F.J. (2005) Renal-cell carcinoma. N.Engl.J.Med. 353, 2477-2490.

Collard,J.M., Malaise,J., Mabrut,J.Y., \& Kestens,P.J. (2003) Skeletonizing en-bloc gastrectomy for adenocarcinoma in Caucasian patients. Gastric.Cancer 6, 210-216.

Combaret,V., Bergeron,C., Brejon,S., Iacono,I., Perol,D., Negrier,S., \& Puisieux,A. (2005) Protein chip array profiling analysis of sera from neuroblastoma patients. Cancer Lett. 228, 91-96.

Coussens,L.M. \& Werb,Z. (2002) Inflammation and cancer. Nature 420, 860-867.

Deichmann,M., Kahle,B., Moser,K., Wacker,J., \& Wust,K. (2004) Diagnosing melanoma patients entering American Joint Committee on Cancer stage IV, C-reactive protein in serum is superior to lactate dehydrogenase. Br.J.Cancer 91, 699-702.

DeNardo,D.G. \& Coussens,L.M. (2007) Inflammation and breast cancer. Balancing immune response: crosstalk between adaptive and innate immune cells during breast cancer progression. Breast Cancer Res. 9, 212.

Deng,R., Lu,Z., Chen,Y., Zhou,L., \& Lu,X. (2007) Plasma proteomic analysis of pancreatic cancer by 2-dimensional gel electrophoresis. Pancreas 34, 310-317.

Dowling,P., O'Driscoll,L., Meleady,P., Henry,M., Roy,S., Ballot,J., Moriarty,M., Crown,J., \& Clynes,M. (2007) 2-D difference gel electrophoresis of the lung squamous cell carcinoma versus normal sera demonstrates consistent alterations in the levels of ten specific proteins. Electrophoresis 28, 4302-4310.

Edgell,T., Martin-Roussety,G., Barker,G., Autelitano,D.J., Allen,D., Grant,P., \& Rice,G.E. (2010) Phase II biomarker trial of a multimarker diagnostic for ovarian cancer. J.Cancer Res.Clin.Oncol. 136, 1079-1088.

Engwegen,J.Y., Mehra,N., Haanen,J.B., Bonfrer,J.M., Schellens,J.H., Voest,E.E., \& Beijnen,J.H. (2007) Validation of SELDI-TOF MS serum protein profiles for renal cell carcinoma in new populations. Lab Invest 87, 161-172.

Erlinger,T.P., Platz,E.A., Rifai,N., \& Helzlsouer,K.J. (2004) C-reactive protein and the risk of incident colorectal cancer. JAMA 291, 585-590. 
Falconer,J.S., Fearon,K.C., Ross,J.A., Elton,R., Wigmore,S.J., Garden,O.J., \& Carter,D.C. (1995) Acute-phase protein response and survival duration of patients with pancreatic cancer. Cancer 75, 2077-2082.

Findeisen,P., Zapatka,M., Peccerella,T., Matzk,H., Neumaier,M., Schadendorf,D., \& Ugurel,S. (2009) Serum amyloid A as a prognostic marker in melanoma identified by proteomic profiling. J.Clin.Oncol. 27, 2199-2208.

Firpo,M.A., Gay,D.Z., Granger,S.R., Scaife,C.L., DiSario,J.A., Boucher,K.M., \& Mulvihill,S.J. (2009) Improved diagnosis of pancreatic adenocarcinoma using haptoglobin and serum amyloid A in a panel screen. World J.Surg. 33, 716-722.

Gao,W.M., Kuick,R., Orchekowski,R.P., Misek,D.E., Qiu,J., Greenberg,A.K., Rom,W.N., Brenner,D.E., Omenn,G.S., Haab,B.B., \& Hanash,S.M. (2005) Distinctive serum protein profiles involving abundant proteins in lung cancer patients based upon antibody microarray analysis. BMC.Cancer 5, 110.

Gerson,J., Evans,A.E., \& Rosen,F.S. (1977) The prognostic value of acute phase reactants in patients with neuroblastoma. Cancer 40, 1655-1658.

Glojnaric,I., Casl,M.T., Simic,D., \& Lukac,J. (2001) Serum amyloid A protein (SAA) in colorectal carcinoma. Clin.Chem.Lab Med. 39, 129-133.

Gockel,I., Dirksen,K., Messow,C.M., \& Junginger,T. (2006) Significance of preoperative Creactive protein as a parameter of the perioperative course and long-term prognosis in squamous cell carcinoma and adenocarcinoma of the oesophagus. World J.Gastroenterol. 12, 3746-3750.

Guillem,P. \& Triboulet,J.P. (2005) Elevated serum levels of C-reactive protein are indicative of a poor prognosis in patients with esophageal cancer. Dis.Esophagus. 18, 146-150.

Gunter,M.J., Stolzenberg-Solomon,R., Cross,A.J., Leitzmann,M.F., Weinstein,S., Wood,R.J., Virtamo,J., Taylor,P.R., Albanes,D., \& Sinha,R. (2006) A prospective study of serum C-reactive protein and colorectal cancer risk in men. Cancer Res. 66, 2483-2487.

Hakomori,S. (1996) Tumor malignancy defined by aberrant glycosylation and sphingo(glyco)lipid metabolism. Cancer Res. 56, 5309-5318.

Hakomori,S. (2002) Glycosylation defining cancer malignancy: new wine in an old bottle. Proc.Natl Acad.Sci.U.S.A 99, 10231-10233.

Hara,M., Matsuzaki,Y., Shimuzu,T., Tomita,M., Ayabe,T., Enomoto,Y., \& Onitsuka,T. (2007) Preoperative serum C-reactive protein level in non-small cell lung cancer. Anticancer Res. 27, 3001-3004.

Hefler,L.A., Concin,N., Hofstetter,G., Marth,C., Mustea,A., Sehouli,J., Zeillinger,R., Leipold,H., Lass,H., Grimm,C., Tempfer,C.B., \& Reinthaller,A. (2008) Serum Creactive protein as independent prognostic variable in patients with ovarian cancer. Clin.Cancer Res. 14, 710-714.

Hefler-Frischmuth,K., Hefler,L.A., Heinze,G., Paseka,V., Grimm,C., \& Tempfer,C.B. (2009) Serum C-reactive protein in the differential diagnosis of ovarian masses. Eur.J.Obstet.Gynecol.Reprod.Biol. 147, 65-68.

Helleman,J., van,d., V, Jansen,M.P., Luider,T.M., van der Burg,M.E., Stoter,G., \& Berns,E.M. $(2008)$ Serum proteomic patterns for ovarian cancer monitoring. Int.J.Gynecol.Cancer $18,985-995$.

Howard,B.A., Wang,M.Z., Campa,M.J., Corro,C., Fitzgerald,M.C., \& Patz,E.F., Jr. (2003) Identification and validation of a potential lung cancer serum biomarker detected by matrix-assisted laser desorption/ionization-time of flight spectra analysis. Proteomics. 3, 1720-1724.

Hsu,P.I., Chen,C.H., Hsieh,C.S., Chang,W.C., Lai,K.H., Lo,G.H., Hsu,P.N., Tsay,F.W., Chen,Y.S., Hsiao,M., Chen,H.C., \& Lu,P.J. (2007) Alpha1-antitrypsin precursor in 
gastric juice is a novel biomarker for gastric cancer and ulcer. Clin.Cancer Res. 13, 876-883.

Ikeda,M., Natsugoe,S., Ueno,S., Baba,M., \& Aikou,T. (2003) Significant host- and tumorrelated factors for predicting prognosis in patients with esophageal carcinoma. Ann.Surg. 238, 197-202.

Il'yasova,D., Colbert,L.H., Harris,T.B., Newman,A.B., Bauer,D.C., Satterfield,S., \& Kritchevsky,S.B. (2005) Circulating levels of inflammatory markers and cancer risk in the health aging and body composition cohort. Cancer Epidemiol.Biomarkers Prev. $14,2413-2418$.

Ilhan,N., Ilhan,N., Ilhan,Y., Akbulut,H., \& Kucuksu,M. (2004) C-reactive protein, procalcitonin, interleukin-6, vascular endothelial growth factor and oxidative metabolites in diagnosis of infection and staging in patients with gastric cancer. World J.Gastroenterol. 10, 1115-1120.

Ito,K., Asano,T., Yoshii,H., Satoh,A., Sumitomo,M., \& Hayakawa,M. (2006) Impact of thrombocytosis and C-reactive protein elevation on the prognosis for patients with renal cell carcinoma. Int.J.Urol. 13, 1365-1370.

Ito,Y., Suzuki,K., Tamakoshi,K., Wakai,K., Kojima,M., Ozasa,K., Watanabe,Y., Kawado,M., Hashimoto,S., Suzuki,S., Tokudome,S., Toyoshima,H., Hayakawa,N., Kato,K., Watanabe,M., Ohta,Y., Maruta,M., \& Tamakoshi,A. (2005) Colorectal cancer and serum C-reactive protein levels: a case-control study nested in the JACC Study. J.Epidemiol. 15 Suppl 2, S185-S189.

Jagdev,S.P., Gregory,W., Vasudev,N.S., Harnden,P., Sim,S., Thompson,D., Cartledge,J., Selby,P.J., \& Banks,R.E. (2010) Improving the accuracy of pre-operative survival prediction in renal cell carcinoma with C-reactive protein. Br.J.Cancer 103, 16491656.

Jamieson,N.B., Glen,P., McMillan,D.C., McKay,C.J., Foulis,A.K., Carter,R., \& Imrie,C.W. (2005) Systemic inflammatory response predicts outcome in patients undergoing resection for ductal adenocarcinoma head of pancreas. Br.J.Cancer 92, 21-23.

Jemal,A., Bray,F., Center,M.M., Ferlay,J., Ward,E., \& Forman,D. (2011) Global cancer statistics. CA Cancer J.Clin.

Jones,J.M., McGonigle,N.C., McAnespie,M., Cran,G.W., \& Graham,A.N. (2006) Plasma fibrinogen and serum C-reactive protein are associated with non-small cell lung cancer. Lung Cancer 53, 97-101.

Kaminska,J., Kowalska,M.M., Nowacki,M.P., Chwalinski,M.G., Rysinska,A., \& Fuksiewicz,M. (2000) CRP, TNF-alpha, IL-1ra, IL-6, IL-8 and IL-10 in blood serum of colorectal cancer patients. Pathol.Oncol.Res. 6, 38-41.

Karin,M. (2006) Nuclear factor-kappaB in cancer development and progression. Nature 441, 431-436.

Kemik,O., Sumer,A., Kemik,A.S., Hasirci,I., Purisa,S., Dulger,A.C., Demiriz,B., \& Tuzun,S. (2010) The relationship among acute-phase response proteins, cytokines and hormones in cachectic patients with colon cancer. World J.Surg.Oncol. 8, 85.

Kim,D.K., Oh,S.Y., Kwon,H.C., Lee,S., Kwon,K.A., Kim,B.G., Kim,S.G., Kim,S.H., Jang,J.S., Kim,M.C., Kim,K.H., Han,J.Y., \& Kim,H.J. (2009) Clinical significances of preoperative serum interleukin-6 and C-reactive protein level in operable gastric cancer. BMC.Cancer 9, 155.

Kimura,M., Tomita,Y., Imai,T., Saito,T., Katagiri,A., Ohara-Mikami,Y., Matsudo,T., \& Takahashi,K. (2001) Significance of serum amyloid A on the prognosis in patients with renal cell carcinoma. Cancer 92, 2072-2075. 
Kodama,J., Miyagi,Y., Seki,N., Tokumo,K., Yoshinouchi,M., Kobashi,Y., Okuda,H., \& Kudo,T. (1999) Serum C-reactive protein as a prognostic factor in patients with epithelial ovarian cancer. Eur.J.Obstet.Gynecol.Reprod.Biol. 82, 107-110.

Komai,Y., Saito,K., Sakai,K., \& Morimoto,S. (2007) Increased preoperative serum C-reactive protein level predicts a poor prognosis in patients with localized renal cell carcinoma. BJU.Int. 99, 77-80.

Koomen,J.M., Shih,L.N., Coombes,K.R., Li,D., Xiao,L.C., Fidler,I.J., Abbruzzese,J.L., \& Kobayashi,R. (2005) Plasma protein profiling for diagnosis of pancreatic cancer reveals the presence of host response proteins. Clin.Cancer Res. 11, 1110-1118.

Lee,J.G., Cho,B.C., Bae,M.K., Lee,C.Y., Park,I.K., Kim,D.J., Ahn,S.V., \& Chung,K.Y. (2009) Preoperative C-reactive protein levels are associated with tumor size and lymphovascular invasion in resected non-small cell lung cancer. Lung Cancer 63, 106-110.

Lee,K., Kye,M., Jang,J.S., Lee,O.J., Kim,T., \& Lim,D. (2004) Proteomic analysis revealed a strong association of a high level of alpha1-antitrypsin in gastric juice with gastric cancer. Proteomics. 4, 3343-3352.

Linke,T., Doraiswamy,S., \& Harrison,E.H. (2007) Rat plasma proteomics: effects of abundant protein depletion on proteomic analysis. J Chromatogr.B Analyt.Technol.Biomed.Life Sci. 849, 273-281.

Lipinska,L., Laskowska-Klita,T., \& Izbicki,T. (1992) Serum acute phase proteins in neuroblastoma children at diagnosis and during the clinical treatment. A preliminary report. Folia Histochem.Cytobiol. 30, 205-206.

Liu,D.H., Wang,X.M., Zhang,L.J., Dai,S.W., Liu,L.Y., Liu,J.F., Wu,S.S., Yang,S.Y., Fu,S., Xiao,X.Y., \& He,D.C. (2007) Serum amyloid A protein: a potential biomarker correlated with clinical stage of lung cancer. Biomed.Environ.Sci. 20, 33-40.

Lukaszewicz-Zajac,M., Mroczko,B., Gryko,M., Kedra,B., \& Szmitkowski,M. (2010) Comparison between clinical significance of serum proinflammatory proteins (IL-6 and CRP) and classic tumor markers (CEA and CA 19-9) in gastric cancer. Clin.Exp.Med.

Maccio,A., Lai,P., Santona,M.C., Pagliara,L., Melis,G.B., \& Mantovani,G. (1998) High serum levels of soluble IL-2 receptor, cytokines, and C reactive protein correlate with impairment of $\mathrm{T}$ cell response in patients with advanced epithelial ovarian cancer. Gynecol.Oncol. 69, 248-252.

Maris,J.M., Hogarty,M.D., Bagatell,R., \& Cohn,S.L. (2007) Neuroblastoma. Lancet 369, 21062120.

McMillan,D.C., Canna,K., \& McArdle,C.S. (2003) Systemic inflammatory response predicts survival following curative resection of colorectal cancer. Br.J.Surg. 90, 215-219.

McSorley,M.A., Alberg,A.J., Allen,D.S., Allen,N.E., Brinton,L.A., Dorgan,J.F., Pollak,M., Tao,Y., \& Helzlsouer,K.J. (2007) C-reactive protein concentrations and subsequent ovarian cancer risk. Obstet.Gynecol. 109, 933-941.

Moshkovskii,S.A., Vlasova,M.A., Pyatnitskiy,M.A., Tikhonova,O.V., Safarova,M.R., Makarov,O.V., \& Archakov,A.I. (2007a) Acute phase serum amyloid A in ovarian cancer as an important component of proteome diagnostic profiling. Proteomics.Clin.Appl. 1, 107-117.

Moshkovskii,S.A., Vlasova,M.A., Pyatnitskiy,M.A., Tikhonova,O.V., Safarova,M.R., Makarov,O.V., \& Archakov,A.I. (2007b) Acute phase serum amyloid A in ovarian cancer as an important component of proteome diagnostic profiling. Proteomics.Clin.Appl. 1, 107-117. 
Mroczko,B., Groblewska,M., Gryko,M., Kedra,B., \& Szmitkowski,M. (2010) Diagnostic usefulness of serum interleukin 6 (IL-6) and C-reactive protein (CRP) in the differentiation between pancreatic cancer and chronic pancreatitis. J.Clin.Lab Anal. 24, 256-261.

Nielsen,H.J., Christensen,I.J., Sorensen,S., Moesgaard,F., \& Brunner,N. (2000) Preoperative plasma plasminogen activator inhibitor type-1 and serum C-reactive protein levels in patients with colorectal cancer. The RANX05 Colorectal Cancer Study Group. Ann.Surg.Oncol. 7, 617-623.

Nosov,V., Su,F., Amneus,M., Birrer,M., Robins,T., Kotlerman,J., Reddy,S., \& Farias-Eisner,R. (2009) Validation of serum biomarkers for detection of early-stage ovarian cancer. Am.J.Obstet.Gynecol. 200, 639-5.

Nozoe,T., Matsumata,T., Kitamura,M., \& Sugimachi,K. (1998) Significance of preoperative elevation of serum C-reactive protein as an indicator for prognosis in colorectal cancer. Am.J.Surg. 176, 335-338.

Nozoe,T., Mori,E., Takahashi,I., \& Ezaki,T. (2008) Preoperative elevation of serum C-reactive protein as an independent prognostic indicator of colorectal carcinoma. Surg.Today 38, 597-602.

Nozoe,T., Saeki,H., \& Sugimachi,K. (2001) Significance of preoperative elevation of serum Creactive protein as an indicator of prognosis in esophageal carcinoma. Am.J.Surg. 182, 197-201.

O'Dowd,C., McRae,L.A., McMillan,D.C., Kirk,A., \& Milroy,R. (2010) Elevated preoperative C-reactive protein predicts poor cancer specific survival in patients undergoing resection for non-small cell lung cancer. J.Thorac.Oncol. 5, 988-992.

O'Hanlon,D.M., Lynch,J., Cormican,M., \& Given,H.F. (2002) The acute phase response in breast carcinoma. Anticancer Res. 22, 1289-1293.

Orchekowski,R., Hamelinck,D., Li,L., Gliwa,E., vanBrocklin,M., Marrero,J.A., Vande Woude,G.F., Feng,Z., Brand,R., \& Haab,B.B. (2005) Antibody microarray profiling reveals individual and combined serum proteins associated with pancreatic cancer. Cancer Res. 65, 11193-11202.

Orimo,A., Gupta,P.B., Sgroi,D.C., Arenzana-Seisdedos,F., Delaunay,T., Naeem,R., Carey,V.J., Richardson,A.L., \& Weinberg,R.A. (2005) Stromal fibroblasts present in invasive human breast carcinomas promote tumor growth and angiogenesis through elevated SDF-1/CXCL12 secretion. Cell 121, 335-348.

Pang,W.W., Abdul-Rahman,P.S., Wan-Ibrahim,W.I., \& Hashim,O.H. (2010) Can the acutephase reactant proteins be used as cancer biomarkers? Int.J Biol.Markers 25, 1-11.

Park,S.Y., Yoon,S.J., Jeong,Y.T., Kim,J.M., Kim,J.Y., Bernert,B., Ullman,T., Itzkowitz,S.H., Kim,J.H., \& Hakomori,S.I. (2010) N-glycosylation status of beta-haptoglobin in sera of patients with colon cancer, chronic inflammatory diseases and normal subjects. Int.J.Cancer 126, 142-155.

Pierce,B.L., Ballard-Barbash,R., Bernstein,L., Baumgartner,R.N., Neuhouser,M.L., Wener,M.H., Baumgartner,K.B., Gilliland,F.D., Sorensen,B.E., McTiernan,A., \& Ulrich,C.M. (2009) Elevated biomarkers of inflammation are associated with reduced survival among breast cancer patients. J.Clin.Oncol. 27, 3437-3444.

Pine,J.K., Fusai,K.G., Young,R., Sharma,D., Davidson,B.R., Menon,K.V., \& Rahman,S.H. (2009) Serum C-reactive protein concentration and the prognosis of ductal adenocarcinoma of the head of pancreas. Eur.J.Surg.Oncol. 35, 605-610.

Polyak,K. \& Hahn,W.C. (2006) Roots and stems: stem cells in cancer. Nat Med 12, 296-300. 
Pujia,A., De,A.F., Scumaci,D., Gaspari,M., Liberale,C., Candeloro,P., Cuda,G., \& Di,F.E. (2010) Highly efficient human serum filtration with water-soluble nanoporous nanoparticles. Int.J Nanomedicine. 5, 1005-1015.

Ramankulov,A., Lein,M., Johannsen,M., Schrader,M., Miller,K., Loening,S.A., \& Jung,K. (2008) Serum amyloid A as indicator of distant metastases but not as early tumor marker in patients with renal cell carcinoma. Cancer Lett. 269, 85-92.

Ravishankaran,P. \& R K (2011) Clinical significance of preoperative serum interleukin-6 and C-reactive protein level in breast cancer patients. World J.Surg.Oncol. 9, 18.

Rigel,D.S. (2010) Epidemiology of melanoma. Semin.Cutan.Med.Surg. 29, 204-209.

Roxburgh,C.S. \& McMillan,D.C. (2010) Role of systemic inflammatory response in predicting survival in patients with primary operable cancer. Future.Oncol 6, 149163.

Saito,K., Tatokoro,M., Fujii,Y., Iimura,Y., Koga,F., Kawakami,S., \& Kihara,K. (2009) Impact of C-reactive protein kinetics on survival of patients with metastatic renal cell carcinoma. Eur.Urol. 55, 1145-1153.

Sandoval,J.A., Turner,K.E., Hoelz,D.J., Rescorla,F.J., Hickey,R.J., \& Malkas,L.H. (2007) Serum protein profiling to identify high-risk neuroblastoma: preclinical relevance of blood-based biomarkers. J.Surg.Res. 142, 268-274.

Shimada,H., Nabeya,Y., Okazumi,S., Matsubara,H., Shiratori,T., Aoki,T., Sugaya,M., Miyazawa,Y., Hayashi,H., Miyazaki,S., \& Ochiai,T. (2003) Elevation of preoperative serum C-reactive protein level is related to poor prognosis in esophageal squamous cell carcinoma. J.Surg.Oncol. 83, 248-252.

Siemes,C., Visser,L.E., Coebergh,J.W., Splinter,T.A., Witteman,J.C., Uitterlinden,A.G., Hofman,A., Pols,H.A., \& Stricker,B.H. (2006) C-reactive protein levels, variation in the C-reactive protein gene, and cancer risk: the Rotterdam Study. J.Clin.Oncol. 24, 5216-5222.

Simpson,W.G., Heys,S.D., Whiting,P.H., Eremin,O., \& Broom,J. (1995) Acute phase proteins and recombinant IL-2 therapy: prediction of response and survival in patients with colorectal cancer. Clin.Exp.Immunol. 99, 143-147.

Su,F., Lang,J., Kumar,A., Ng,C., Hsieh,B., Suchard,M.A., Reddy,S.T., \& Farias-Eisner,R. (2007) Validation of candidate serum ovarian cancer biomarkers for early detection. Biomark.Insights. 2, 369-375.

Tartour,E., Dorval,T., Mosseri,V., Deneux,L., Mathiot,C., Brailly,H., Montero,F., Joyeux,I., Pouillart,P., \& Fridman,W.H. (1994) Serum interleukin 6 and C-reactive protein levels correlate with resistance to IL-2 therapy and poor survival in melanoma patients. Br.J.Cancer 69, 911-913.

Teng,P.N., Bateman,N.W., Hood,B.L., \& Conrads,T.P. (2010) Advances in proximal fluid proteomics for disease biomarker discovery. J Proteome.Res. 9, 6091-6100.

Tingstedt,B., Johansson,P., Andersson,B., \& Andersson,R. (2007) Predictive factors in pancreatic ductal adenocarcinoma: role of the inflammatory response. Scand.J.Gastroenterol. 42, 754-759.

Tolson,J., Bogumil,R., Brunst,E., Beck,H., Elsner,R., Humeny,A., Kratzin,H., Deeg,M., Kuczyk,M., Mueller,G.A., Mueller,C.A., \& Flad,T. (2004) Serum protein profiling by SELDI mass spectrometry: detection of multiple variants of serum amyloid alpha in renal cancer patients. Lab Invest 84, 845-856.

Trichopoulos,D., Psaltopoulou,T., Orfanos,P., Trichopoulou,A., \& Boffetta,P. (2006) Plasma C-reactive protein and risk of cancer: a prospective study from Greece. Cancer Epidemiol.Biomarkers Prev. 15, 381-384. 
Trichopoulos,D., Tzonou,A., Kalapothaki,V., Sparos,L., Kremastinou,T., \& Skoutari,M. (1990) Alpha 1-antitrypsin and survival in pancreatic cancer. Int.J.Cancer 45, 685686.

Tsavaris,N., Kosmas,C., Kopterides,P., Tsikalakis,D., Skopelitis,H., Sakelaridi,F., Papadoniou,N., Tzivras,M., Balatsos,V., Koufos,C., \& Archimandritis,A. (2005) Retinol-binding protein, acute phase reactants and Helicobacter pylori infection in patients with gastric adenocarcinoma. World J.Gastroenterol. 11, 7174-7178.

Wang,C.Y., Hsieh,M.J., Chiu,Y.C., Li,S.H., Huang,H.W., Fang,F.M., \& Huang,Y.J. (2009) Higher serum C-reactive protein concentration and hypoalbuminemia are poor prognostic indicators in patients with esophageal cancer undergoing radiotherapy. Radiother.Oncol. 92, 270-275.

Wang,Y., Jiang,H., Dai,D., Su,M., Martinka,M., Brasher,P., Zhang,Y., McLean,D., Zhang,J., Ip,W., Li,G., Zhang,X., \& Zhou,Y. (2010) Alpha 1 antichymotrypsin is aberrantly expressed during melanoma progression and predicts poor survival for patients with metastatic melanoma. Pigment Cell Melanoma Res. 23, 575-578.

Ward,A.M., Cooper,E.H., Turner,R., Anderson,J.A., \& Neville,A.M. (1977) Acute-phase reactant protein profiles: an aid to monitoring large bowel cancer by CEA and serum enzymes. Br.J.Cancer 35, 170-178.

Wood,S.L., Rogers,M., Cairns,D.A., Paul,A., Thompson,D., Vasudev,N.S., Selby,P.J., \& Banks,R.E. (2010) Association of serum amyloid A protein and peptide fragments with prognosis in renal cancer. Br.J.Cancer 103, 101-111.

Ye,B., Cramer,D.W., Skates,S.J., Gygi,S.P., Pratomo,V., Fu,L., Horick,N.K., Licklider,L.J., Schorge,J.O., Berkowitz,R.S., \& Mok,S.C. (2003) Haptoglobin-alpha subunit as potential serum biomarker in ovarian cancer: identification and characterization using proteomic profiling and mass spectrometry. Clin.Cancer Res. 9, 2904-2911.

Yu,K.H., Rustgi,A.K., \& Blair,I.A. (2005) Characterization of proteins in human pancreatic cancer serum using differential gel electrophoresis and tandem mass spectrometry. J.Proteome.Res. 4, 1742-1751.

Zeng,Z., Hincapie,M., Haab,B.B., Hanash,S., Pitteri,S.J., Kluck,S., Hogan,J.M., Kennedy,J., \& Hancock,W.S. (2010) The development of an integrated platform to identify breast cancer glycoproteome changes in human serum. J Chromatogr.A 1217, 3307-3315.

Zhang,S.M., Buring,J.E., Lee,I.M., Cook,N.R., \& Ridker,P.M. (2005) C-reactive protein levels are not associated with increased risk for colorectal cancer in women. Ann.Intern.Med. 142, 425-432.

Zhang,Z., Bast,R.C., Jr., Yu,Y., Li,J., Sokoll,L.J., Rai,A.J., Rosenzweig,J.M., Cameron,B., Wang,Y.Y., Meng,X.Y., Berchuck,A., van Haaften-Day,C., Hacker,N.F., de Bruijn,H.W., van der Zee,A.G., Jacobs,I.J., Fung,E.T., \& Chan,D.W. (2004) Three biomarkers identified from serum proteomic analysis for the detection of early stage ovarian cancer. Cancer Res. 64, 5882-5890.

Zingg,U., Forberger,J., Rajcic,B., Langton,C., \& Jamieson,G.G. (2010) Association of Creactive protein levels and long-term survival after neoadjuvant therapy and esophagectomy for esophageal cancer. J.Gastrointest.Surg. 14, 462-469. 
ACUTE PHASE PROTEINS AS EARIY NON-SPECIFIC BIOMARKERS OF HUMAN ANO VETERINARY DISEASES

Edited by Francheo Vees

\section{Acute Phase Proteins as Early Non-Specific Biomarkers of Human and Veterinary Diseases}

Edited by Prof. Francisco Veas

ISBN 978-953-307-873-1

Hard cover, 408 pages

Publisher InTech

Published online 10, October, 2011

Published in print edition October, 2011

The two volumes of Acute Phase Proteins book consist of chapters that give a large panel of fundamental and applied knowledge on one of the major elements of the inflammatory process during the acute phase response, i.e., the acute phase proteins expression and functions that regulate homeostasis. We have organized this book in two volumes - the first volume, mainly containing chapters on structure, biology and functions of APP, the second volume discussing different uses of APP as diagnostic tools in human and veterinary medicine.

\section{How to reference}

In order to correctly reference this scholarly work, feel free to copy and paste the following:

W. Shannon Orr, Linda H. Malkas, Robert J. Hickey and John A. Sandoval (2011). Acute Phase Proteins as Cancer Biomarkers, Acute Phase Proteins as Early Non-Specific Biomarkers of Human and Veterinary Diseases, Prof. Francisco Veas (Ed.), ISBN: 978-953-307-873-1, InTech, Available from: http://www.intechopen.com/books/acute-phase-proteins-as-early-non-specific-biomarkers-of-human-andveterinary-diseases/acute-phase-proteins-as-cancer-biomarkers

\section{INTECH}

open science | open minds

\section{InTech Europe}

University Campus STeP Ri Slavka Krautzeka 83/A 51000 Rijeka, Croatia Phone: +385 (51) 770447

Fax: +385 (51) 686166 www.intechopen.com

\section{InTech China}

Unit 405, Office Block, Hotel Equatorial Shanghai No.65, Yan An Road (West), Shanghai, 200040, China 中国上海市延安西路65号上海国际贵都大饭店办公楼405单元 Phone: +86-21-62489820

Fax: $+86-21-62489821$ 
(C) 2011 The Author(s). Licensee IntechOpen. This is an open access article distributed under the terms of the Creative Commons Attribution 3.0 License, which permits unrestricted use, distribution, and reproduction in any medium, provided the original work is properly cited. 